\title{
KOCKOVAELLA, A NEW BALLISTOSPORE-FORMING ANAMORPHIC YEAST GENUS
}

\author{
TAKASHI NAKASE,* MUTSUMI ITOH, AKIKO TAKEMATSU, \\ KOZABURO MIKATA, ${ }^{1}$ ISAO BANNO, ${ }^{1}$ AND YUZO YAMADA ${ }^{2}$ \\ Japan Collection of Microorganisms, The Institute of Physical and Chemical \\ Research (RIKEN), Hirosawa, Wako, Saitama 351-01, Japan \\ ${ }^{1}$ Institute for Fermentation, Osaka, Jusohonmachi, Yodogawa-ku, Osaka 532, Japan \\ ${ }^{2}$ Laboratory of Applied Microbiology, Department of Agricultural Chemistry, \\ Shizuoka University, Ohya, Shizuoka 422, Japan
}

(Received January 30, 1991)

\begin{abstract}
A new genus Kockovaella Nakase, Banno et Yamada in the Hyphomycetes is described for yeasts that reproduce by non-ballistosporous stalked conidia, ballistospores and budding yeast cells. Strains in this genus have Q-10 as the major isoprenologue of ubiquinones, contain xylose in the cells, and are positive to diazonium blue $B$ reaction. Two new species, Kockovaella thailandica (type species) and $K$. imperatae, are described in the genus. Kockovaella thailandica has a $\mathrm{G}+\mathrm{C}$ content of DNA of 49.5 $\mathrm{mol} \%$ (from $T_{\mathrm{m}}$ ) or $47.7-48.4 \mathrm{~mol} \%$ (by HPLC) and forms asymmetrical kidney-shaped or ellipsoidal ballistospores, whereas $K$. imperatae has a $\mathrm{G}$ + C content of DNA of $52.3 \mathrm{~mol} \%$ (from $T_{\mathrm{m}}$ ) or $49.0 \mathrm{~mol} \%$ (by HPLC) and forms symmetrical globose to napiform ballistospores. Electrophoretic comparison of eight enzymes and DNA similarity indicated that $K$. thailandica and $K$. imperatae are distinct species from each other. The partial sequencing study on $18 \mathrm{~S}$ ribosomal RNA suggested a close relationship among species of Kockovaella, Fellomyces and Sterigmatosporidium. The latter two genera resemble Kockovaella in the production of non-ballistosporous stalked conidia and the presence of xylose in the cells but produce neither ballistospores nor budding yeast cells.
\end{abstract}

In the latest edition of "The Yeasts, a Taxonomic Study" published in 1984 (13), only two anamorphic genera, Bullera and Sporobolomyces, and a single teleomorphic genus, Sporidiobolus, are listed in sporobolomycetaceous ballistospore-forming yeasts. After the publication of that monograph, two new genera,

* Address reprint requests to: Dr. T. Nakase, Japan Collection of Microorganisms, The Institute of Physical and Chemical Research (RIKEN), Hirosawa 2-1, Wako, Saitama 351-01, Japan. 
Bensingtonia and Ballistosporomyces, were described in this group of yeasts.

The genus Bensingtonia was described by Ingold (10) in 1986 based on a single isolate from a plant in England with a vague definition. Nakase and Boekhout (21) emended the diagnosis of Bensingtonia to permit the inclusion of all of the species of ballistospore-forming yeasts which have Q-9 as the major component of ubiquinones and lack xylose in the cells. Nine species are now included in this genus $(21,25,39)$.

In 1989, Nakase et al. (26) described a new genus Ballistosporomyces based on two isolates, which were classified into two different species, from leaves of plants in Japan. Ballistosporomyces is characterized by the reproduction by ballistospores and non-ballistosporous stalked conidia, Q-10 as the major ubiquinone, and the lack of xylose in the cells. Budding cells were not found in strains of this genus.

During a survey on ballistospore-forming yeasts in Thailand in 1987, three strains of hitherto undescribed yeasts were isolated from leaves of Oryza sativa L. and Imperata cylindrica (L.) Beauv. They are characterized by the reproduction of ballistospores, non-ballistosporous stalked conidia and budding cells, by Q-10 as the major ubiquinone and the presence of xylose in the cells, and cannot be assigned to any known genera of ballistospore-forming yeasts. A new genus Kockovaella is proposed for these yeasts.

\section{MATERIALS AND METHODS}

Strains used. The three strains used in this study were isolated from plant materials collected in the suburbs of Bangkok, Thailand, in December, 1987, by the ballistospore fall technique of Derx (2) using YM agar (Difco Labs) plates. Strain K-35 was isolated from a dead leaf of Oryza sativa. Strains K-94 and K-97 were isolated from the leaves of Imperata cylindrica. Bullera alba JCM 2954 (=CBS 501), B. megalospora JCM 5269 (=CBS 7236), Fellomyces fuzhouensis IFO 10374 (=JCM 7367), F. polyborus IFO 10120 (=JCM 6908), F. penicillatus IFO 10119 (=JCM 6907), Sterigmatosporidium polymorphum IFO 10121 (=JCM 6902) and Kurtzmanomyces nectairei IFO 10118 (= JCM 6906) were used for chemotaxonomic comparison.

Examination of morphological, physiological and biochemical characteristics. Most of methods used to examine the morphological, physiological, and biochemical characteristics were those described in "The Yeasts, a Taxonomic Study" $(33,34)$. Assimilation of nitrogen compounds was examined on solid media with starved inoculum (18). The vitamin requirement was investigated according to Komagata and Nakase (12). The maximum growth temperature was determined in YM broth (Difco Labs) using metal block baths.

Examination by scanning electron microscopy was carried out as follows: Cells grown in YM broth were fixed with 1\% glutaraldehyde and then with $1 \%$ osmic acid in the phosphate buffer ( $\mathrm{pH}$ 7.2). Ballistospores produced on colony on corn meal agar were fixed with vapor of $1 \%$ osmic acid. The fixed samples were 
dehydrated by passing at 15 min intervals through a graded acetone concentration series of 30 to 100\%. After critical-point drying in an HPC-2 (Hitachi Ltd.), the preparation was coated with gold at $1.2 \mathrm{kV}, 5 \mathrm{~mA}$, in vacuo and examined in a scanning electron microscope JSMT-20 (JEOL Ltd.) at $20 \mathrm{kV}$.

Analysis of ubiquinones. Ubiquinones were extracted and purified according to the procedures reported in a previous paper (19) by using cells harvested in the stationary growth phase. Ubiquinone isoprenologues were identified by high performance liquid chromatography (HPLC) and by comparing their retention times with those of standard ubiquinones. HPLC was performed on an LC-6A liquid chromatograph (Shimadzu Corporation) fitted with a Zorbax ODS column $(4.6 \mathrm{~mm} \times 25 \mathrm{~cm})$. Ubiquinones were eluted with a mobile phase of methanolisopropanol $(2: 1, \mathrm{v} / \mathrm{v})$ at $2.0 \mathrm{ml} / \mathrm{min}$, and detected at $275 \mathrm{~nm}$.

Isolation and purification of DNA. The DNAs were isolated from $200 \mathrm{mg}$ of wet cells harvested from YPD broth (yeast extract, Difco $10 \mathrm{~g}$; peptone, Difco 10 $\mathrm{g}$; and glucose $20 \mathrm{~g}$; water $1,000 \mathrm{ml}$ ). The DNA was extracted and purified according to the method described by Langtime (15). DNA samples having an $A_{260 / 280}$ ratio of 1.8 to 1.9 were used to determine the DNA base composition (mol $\% \mathrm{G}+\mathrm{C}$ ) and in the DNA-DNA reassociation experiment.

Determination of DNA base composition. The $\mathrm{mol} \% \mathrm{G}+\mathrm{C}$ was determined by two different methods. In the first method, it was calculated from the thermal denaturation temperature $\left(T_{\mathrm{m}}\right)$ measured in $0.5 \times \mathrm{SSC}$ solution. DNA from Candida parapsilosis JCM 1785 (=CBS 604) was used as the reference at each $T_{\mathrm{m}}$ determination. The mol $\% \mathrm{G}+\mathrm{C}$ was corrected to the reference DNA whose mol $\% \mathrm{G}+\mathrm{C}$ was 40.8 .

In the second method, deoxyribonucleosides were analyzed by HPLC after hydrolysis of DNA according to the procedure described by Suzuki (31). DNA was hydrolyzed with nuclease $\mathrm{P}_{1}$ (Sigma Chemical Co.) then the resulting deoxyribonucleotides were digested with alkaline phosphatase (Sigma). The molar ratio of deoxyribonucleosides in the reaction mixture was analyzed by HPLC performed on an LC-6A liquid chromatograph (Shimadzu Corporation) fitted with a Cosmosil $\mathrm{C}_{18}$ column (Nakarai Chemicals Co.). Deoxyribonucleosides were eluted with a mobile phase of $0.2 \mathrm{M} \mathrm{NH} \mathrm{NH}_{4} \mathrm{HO}_{4}$ solution supplemented with 1/20 volume of acetonitrile. The standard deoxyribonucleoside mixture was prepared by digesting the standard deoxyribonucleotide mixture of a DNA-GC Kit (Yamasa Shoyu Co.) with alkaline phosphatase.

DNA-DNA reassociation experiment. The microplate-hybridization method using photobiotin labeled DNA probe developed by Ezaki et al. $(3,4)$ was applied to determine the DNA similarity, with minor modification as mentioned below. A heat-denatured target yeast DNA (400 ng) was immobilized in the wells of a microplate (Immuno Plate II, Nunc Inc.) at $28^{\circ} \mathrm{C}$ overnight. After washing, the microplate was dried at $60^{\circ} \mathrm{C}$ for $2 \mathrm{~h}$. One tenth $\mathrm{ml}$ of hybridization solution containing $50 \mathrm{mg}$ of dextran sulfate and $0.5 \mu \mathrm{g}$ of heat-denatured, biotinylated probe DNA per milliliter was added to the wells. Hybridization was performed at 
$42^{\circ} \mathrm{C}$ for $24 \mathrm{~h}$. After washing, binding of streptoavidin- $\beta$-galactosidase, and adding 4-methylumbelliferyl- $\beta$-D-galactopyranoside, fluorescence intensity in the wells was measured with a microplate reader MTP-32 (Corona Electric Co., Ltd.).

Comparison of enzyme patterns. The electrophoretic enzyme patterns were investigated by the slab-gel electrophoresis technique reported by Yamazaki and Komagata (43) as described in a previous paper (18). The similarity values in enzyme patterns were calculated by the following formula: Similarity $(\%)=\{2$ $\mathrm{NAB} /(\mathrm{NA}+\mathrm{NB})\} \times 100(\mathrm{NAB}$, the number of enzyme bands with identical $R m$ values; NA, the number of enzyme bands of strain $A$; NB, the number of enzyme bands of strain B).

Analysis of xylose in the cells. Xylose in the whole cell hydrolyzates was analyzed as follows according to the method of Suzuki and Nakase (32): Cells grown in YM broth supplemented with $2 \%$ glucose were harvested in their logarithmic growth phase, and dried with acetone. Dried cells $(50-100 \mathrm{mg})$ were hydrolyzed with $1 \mathrm{ml}$ of $2 \mathrm{M}$ trifluoroacetic acid at $100^{\circ} \mathrm{C}$ for $3 \mathrm{~h}$. After cooling, the hydrolyzate was filtered with filter paper and evaporated to dryness under reduced pressure. The residue was dissolved in $0.5 \mathrm{ml}$ of water, neutralized with Amberlite IRA 410 (OH form), filtered with a disposable filter unit (Shodex DT ED-13, Showa Denko Co.), and subjected to HPLC. HPLC analysis was performed on a Shodex SP 1010 column (Showa Denko) with water as the mobile phase at a flow rate of $0.8 \mathrm{ml} / \mathrm{min}$ and at $80^{\circ} \mathrm{C}$, and a Shodex RS pak DC-613 column with acetonitrile-water $(80: 20, \mathrm{v} / \mathrm{v})$ as the mobile phase at a flow rate of $0.8 \mathrm{ml} / \mathrm{min}$ at $75^{\circ} \mathrm{C}$. A refractive index monitor was used to detect carbohydrates.

Partial sequence determination of $18 S$ rRNA. The rRNAs were isolated and purified according to Yamada and Kawasaki (40). The partial sequences of $18 \mathrm{~S}$ rRNA were determined according to the method of Lane et al. (14) using reverse transcriptase. The oligonucleotide DNA primer used in the experiment was $5^{\prime}$. ACGGGCGGTGTGTAC-3' which is complementary to the sequence of the positions (in Saccharomyces cerevisiae) of 1641 through 1627 (17).

\section{RESULTS AND DISCUSSION}

Descriptions of new taxa

Kockovaella Nakase, Banno et Yamada, anam.-gen. nov.

Genus ad Hyphomycetes pertinens.

Cellulae vegetativae sphaericae, subovales, ovales vel reniformes, propagantes formatione conidiorum stipitatorum aut ballistosporum et raro gemmarum blasticarum. Ballistosporae globosae, napiformes, reniformes vel ellipsoidales. Hyphae fortasse formantur. Fermentatio nulla. Diazonium caeruleum B positivum. Systema ubiquinoni majus Q-10. Xylosum in cellulis praesens. Teleomorphosis ignota.

Species typica: Kockovaella thailandica Nakase, Banno et Yamada.

Etymologia: Ko.cho.va.el'la. M.L. dim.fem.n. Kockovaella; named for Anna 
Kocková-Kratochvílová, a yeast taxonomist in Czechoslovakia.

Vegetative cells are spherical, short oval, oval or kidney-shaped, reproduce by stalked conidia and ballistospores, rarely by budding cells. Ballistospores are globose, napiform, kidney-shaped or ellipsoidal. Hyphae may be produced. Fermentation is absent. Diazonium blue B color test is positive. Major ubiquinone is Q-10. Xylose in the cells is present. Teleomorph unknown.

Type species: Kockovaella thailandica Nakase, Banno et Yamada.

Kockovaella thailandica Nakase, Banno et Yamada, sp. nov.

In liquid YM post dies 3 ad $25^{\circ} \mathrm{C}$, cellulae vegetativae sphaericae vel ovoideae, $1.5-5.9 \times 4.0-10.0 \mu \mathrm{m}$, singulae, binae, in catenis aut in fasciculis, propagantes formatione conidiorum stipitatorum et raro gemmarum blasticarum. Conidia stipitata holoblastice productantur; stipites ex cellula conidiogena multilateraliter et holoblastice exorientes, et raro sympodice proliferentes. Interdum conidia in catenis et in fasciculis formantur. Separatio ex cellula conidiogena ad positonem distaleum in stipite praesens. Post unum mensem ad $17^{\circ} \mathrm{C}$, pellicula fragilis et sedimentum formantur. Cultura in agaro YM, griseo-aurantiaca, levis, nitida, mollis vel mucosa, et margine glabra; conidia stipitata et ballistosporae formantur. Ballistosporae reniformes aut ellipsoidales, $1.3-5.3 \times 2.1-9.2 \mu \mathrm{m}$. Mycelium et pseudomycelium non formantur.

Fermentatio nulla. Glucosum, galactosum, L-sorbosum (fortasse lente, vel lente \& exiguum), sucrosum, maltosum, cellobiosum, trehalosum, lactosum, melibiosum, raffinosum, melezitosum, amylum solubile, D-xylosum, L-arabinosum, D-arabinosum (fortasse lente, vel lente et exiguum), D-ribosum, L-rhamnosum, glycerolum (lente et exiguum, vel nullum), D-mannitolum, D-glucitolum, salicinum (exiguum, vel nullum), D-glucosaminum, $N$-acetyl-D-glucosaminum, acidum 2ketogluconicum, acidum 5-ketogluconicum, acidum D-glucuronicum, acidum Dgalacuturonicum, acidum succinicum (exiguum), acidum citricum (exiguum, vel nullum) et inositolum (lente, vel nullum) assimilantur at non inulinum, ethanolum, methanolum, erythritolum, ribitolum (vel lente et exiguum), galactitolum, $\alpha$ methyl-D-glucosidum (vel lente), glucono- $\delta$-lactonum, acidum DL-lacticum nec hexadecanum. Kalium nitricum non assimilatur. Maxima temperatura crescentiae: $32-33^{\circ} \mathrm{C}$. Ad crescentiam thiaminum necessarium est. Materia amyloidea iodophila non formatur. Ureum hydrolysatur. Diazonium caeruleum B: Positivum. Proportio molaris guanini + cytosini in acido deoxyribonucleinico: $49.5 \mathrm{~mol} \%$ (ex $T_{\mathrm{m}}$ ), 47.7-48.4 mol\% (per HPLC). Ubiquinonum majus: Q-10. Xylosum in cellulis praesens. Teleomorphosis ignota.

Holotypus: Isolatus ex folio Imperatae cylindricae, Thailandia, xii, 1987, T. Nakase et B. Fungsin, JCM 7824 (originaliter ut K-94) conservatur in collectionibus culturarum quas 'Japan Collection of Microorganisms,' Wako, Saitama sustentat. 
Growth in YM broth: After 3 days at $25^{\circ} \mathrm{C}$, the vegetative cells are spherical to ovoidal, $1.6-4.6 \times 2.0-7.7 \mu \mathrm{m}$, single, in pairs, or in clusters, reproduced by conidiation (Figs. 1C, 2B, 2C) or rarely by budding (Fig. 1I). Conidia are produced holoblastically on a sterigma-like stalk. Stalks develop multilaterally and holoblastically from a conidiogenous cell (Figs. 1C, 1H, 2I) and rarely proliferate
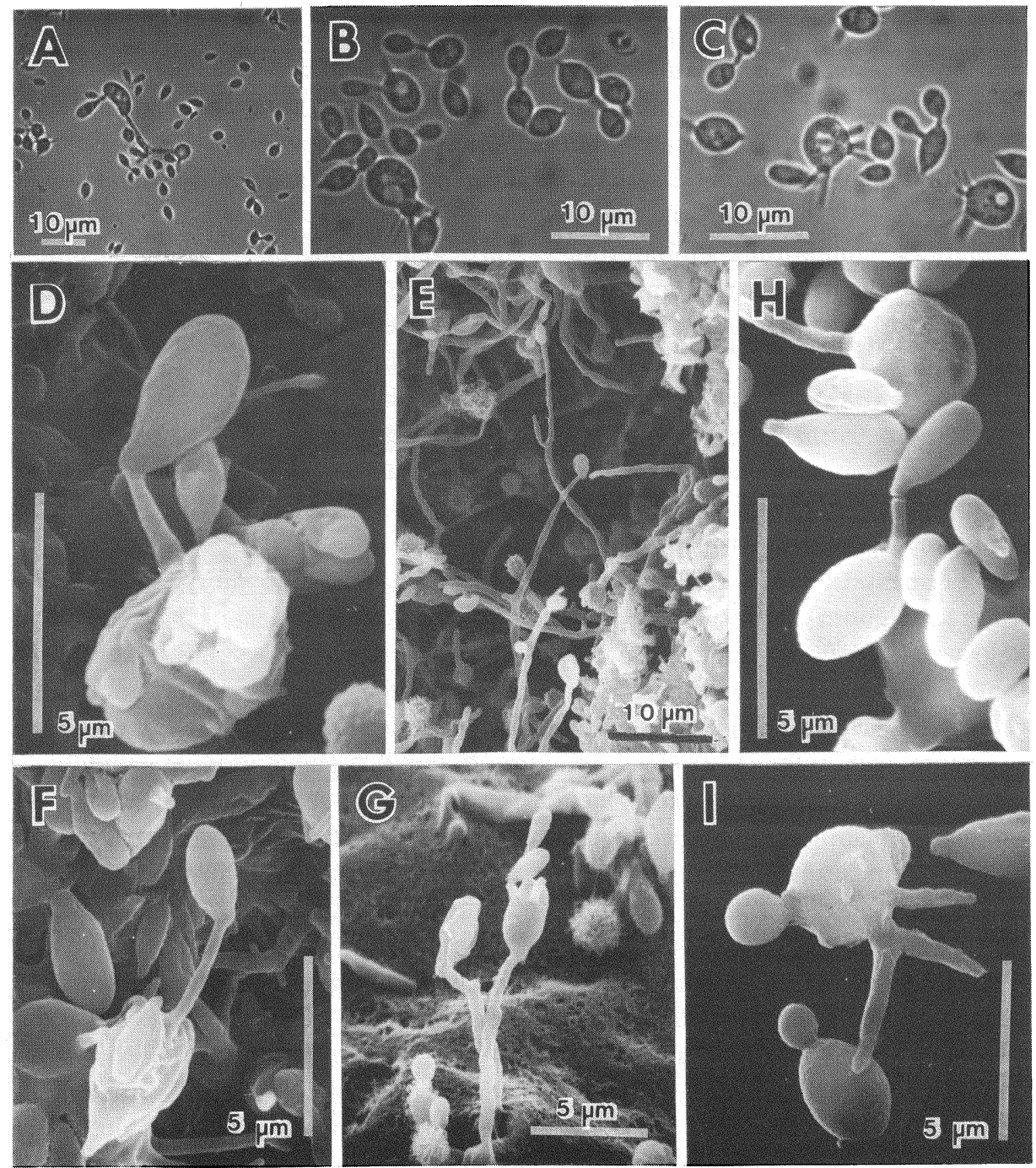

Fig. 1. Kockovaella thailandica K-94 (A, B and C, light microscopy; D, E, F, G, H and I, scanning electron microscopy). A, a ballistospore from which a stalked conidium is developed; $\mathrm{B}$ and $\mathrm{C}$, stalked conidia; D and F, ballistospores; E, ballistospores formed on long sterigmata; G, stalked conidium developing from ballistospore; H, stalked conidia; I, sympodial formation of stalked conidia and budding. 

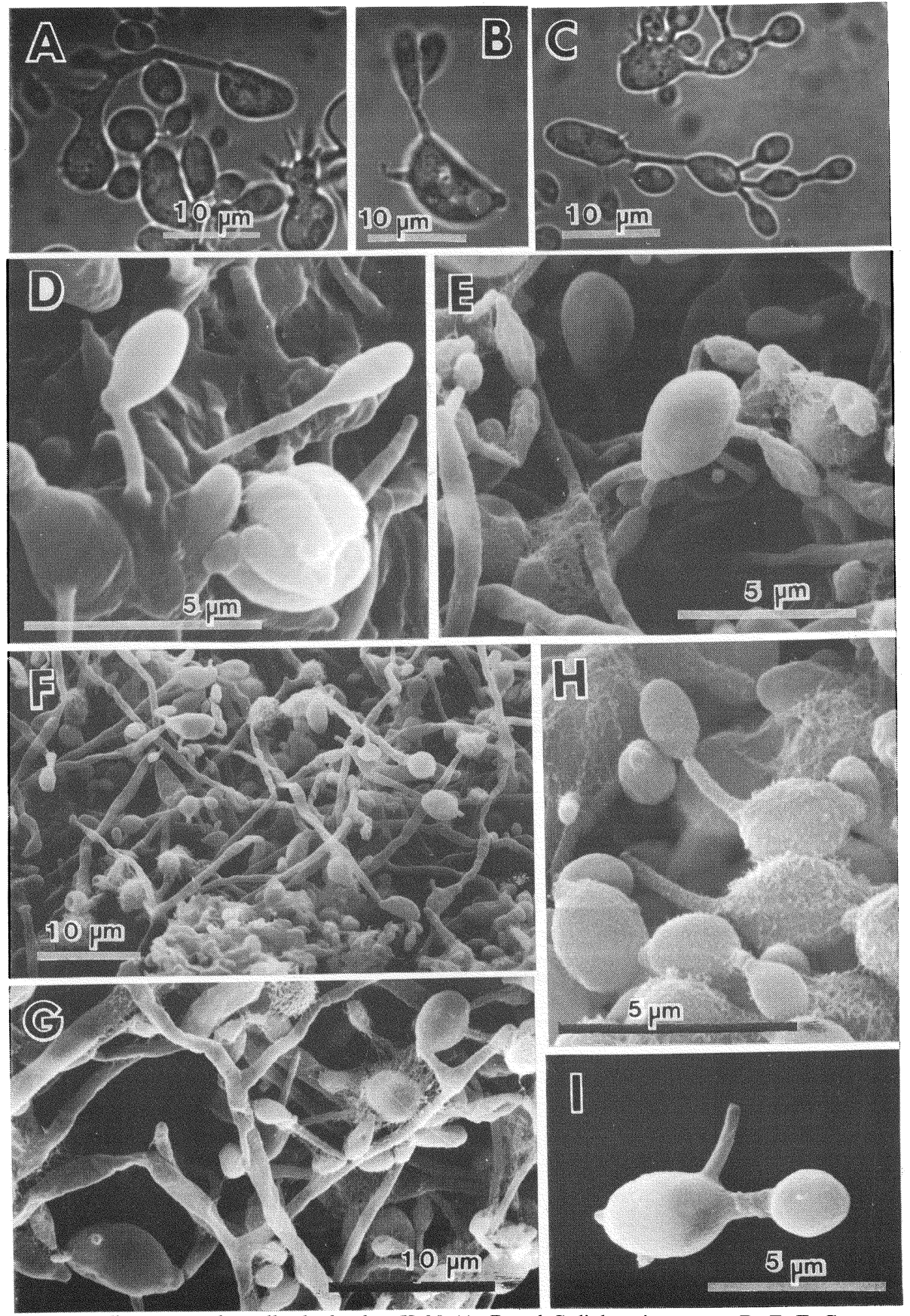

Fig. 2. Kockovaella thailandica K-35 (A, B and C, light microscopy; D, E, F, G, $H$ and I, scanning electron microscopy). A, ballistospores; B, stalked conidium developing from ballistospore; C, stalked conidia in cluster; D, ballistospore; E, ballistospore from which stalked conidium is developed; F and G, ballistosporeformation on branched long sterigmata; $\mathbf{H}$ and $\mathbf{I}$, stalked conidia. 

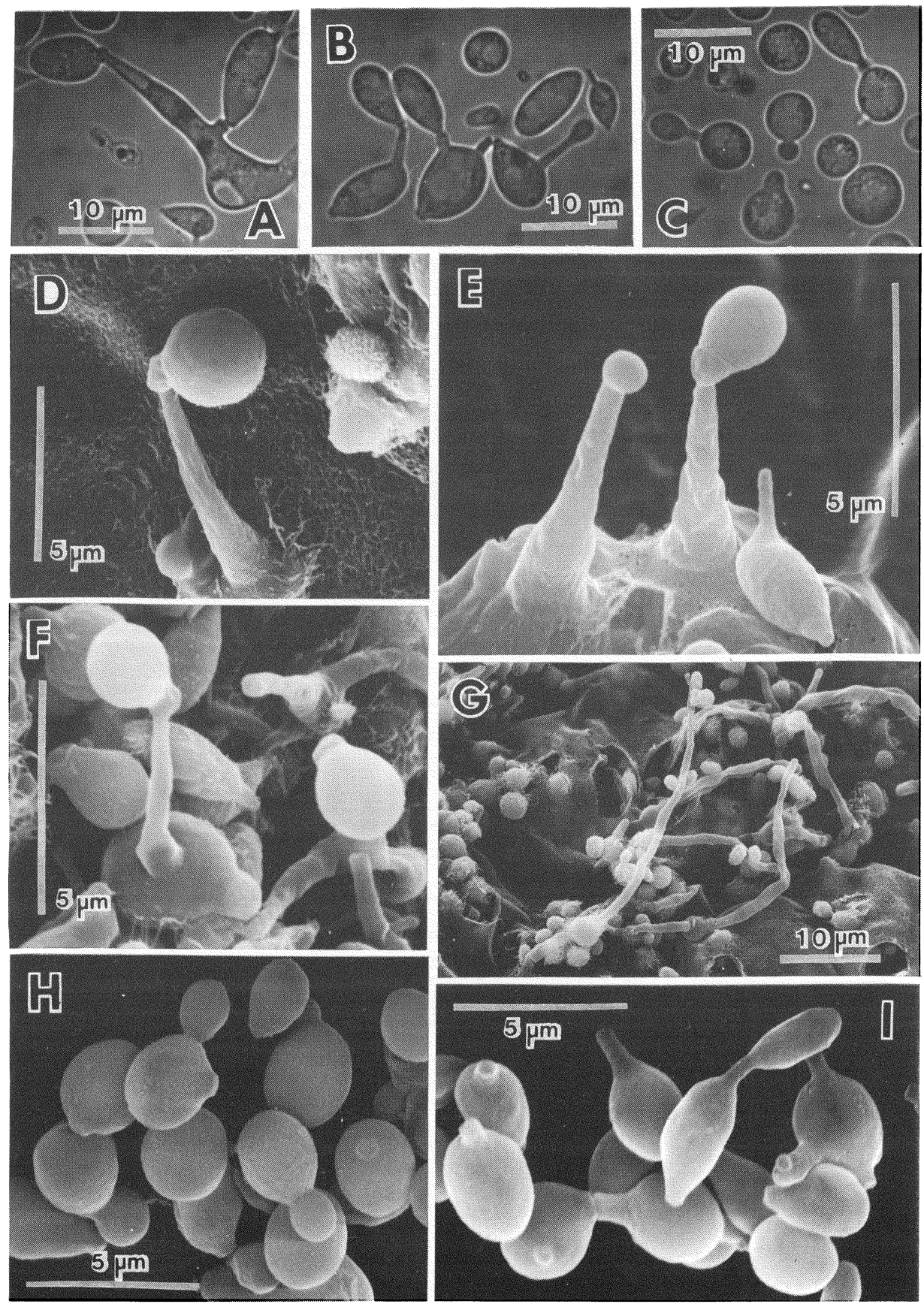

Fig. 3. Kockovaella imperatae K-97 (A, B and C, light microscopy; D, E, F, G, $\mathbf{H}$ and I, scanning electron microscopy). A, a ballistospore and a stalked conidium; B, stalked conidia; C, stalked conidium-formation and budding; D, E and F, ballistospores on sterigmata; G, ballistospore-formation on long sterigmata; $\mathbf{H}$, budding cells and stalked conidia resembling buds; I, stalked conidia. 
sympodially (Fig. 1I), and measure $4-15 \mu \mathrm{m}$ in length and $0.3-0.6 \mu \mathrm{m}$ in width. Daughter cells generally separate at the distal position of stalks (Fig. 1H). Occasionally chains and clusters of stalked conidia are formed (Fig. 2A). A sediment is formed. After one month at $17^{\circ} \mathrm{C}$, a fragile pellicle and a sediment are present. There may be as many as 12 stalks on a cell.

Growth on YM agar: After one month at $17^{\circ} \mathrm{C}$, the streak culture is greyish orange, smooth, shining, soft to mucous and has an entire margin. Stalked conidia and ballistospores are formed.

Dalmau plate culture on corn meal agar: Mycelia and pseudomycelia are not formed.

Ballistospores: Ballistospores are produced on corn meal agar and YM agar. They are kidney-shaped or ellipsoidal, 1.3-5.3 $\times 2.1-9.2 \mu \mathrm{m}$, formed on sterigma (Figs. 1A, 1D, 2A, 2D), which proliferates singly or in branches (Figs. 1E, 2G). The sterigmata occasionally become much longer than $30 \mu \mathrm{m}$ (Figs. 1E, 2F).

Fermentation: Absent.

Assimilation of carbon compounds:

\begin{tabular}{|c|c|c|c|}
\hline Glucose & + & Glycerol & + (latent \& weak) \\
\hline Galactose & + & & or - \\
\hline \multirow[t]{2}{*}{ L-Sorbose } & \multirow{2}{*}{$\begin{array}{l}\text { (may be latent, } \\
\text { latent \& weak) }\end{array}$} & Erythritol & - \\
\hline & & Ribitol & - or + (latent $\&$ \\
\hline Sucrose & + & & weak) \\
\hline Maltose & + & Galactitol & - \\
\hline Cellobiose & + & D-Mannitol & + \\
\hline Trehalose & + & D-Glucitol & + \\
\hline Lactose & + & $\alpha$-Methyl-D-glucoside & - or + (latent) \\
\hline Melibiose & + & Salicin & + (weak) or - \\
\hline Raffinose & + & Glucono- $\delta$-lactone & - \\
\hline Melezitose & + & D-Glucosamine & + \\
\hline Inulin & - & $N$-Acetyl-D-glucosamine & + \\
\hline Soluble starch & + & 2-Ketogluconic acid & + \\
\hline D-Xylose & + & 5-Ketogluconic acid & + \\
\hline L-Arabinose & + & D-Glucuronic acid & + \\
\hline \multirow[t]{2}{*}{ D-Arabinose } & \multirow{2}{*}{$\begin{array}{r}+ \text { (may be latent, } \\
\text { latent \& weak) }\end{array}$} & D-Galacturonic acid & + \\
\hline & & DL-Lactic acid & - \\
\hline D-Ribose & + & Succinic acid & $+($ weak $)$ \\
\hline L-Rhamnose & + & Citric acid & $+($ weak $)$ or - \\
\hline Ethanol & - & Inositol & + (latent) or - \\
\hline Methanol & - & Hexadecane & - \\
\hline \multicolumn{4}{|c|}{ Assimilation of nitrogen compounds: } \\
\hline \multirow{3}{*}{$\begin{array}{l}\text { Ammonium sul } \\
\text { Potassium nitra } \\
\text { Sodium nitrite }\end{array}$} & lfate + Ethylamin & e hydrochloride & \\
\hline & ate - L-Lysine 1 & lydrochloride $\quad+$ & \\
\hline & - Cadaverin & e dihydrochloride + (late & ent \& weak) or - \\
\hline
\end{tabular}


Vitamin required: Thiamine.

Growth on 50\% (w/w) glucose-yeast extract agar: Negative.

Production of starch-like substances: Negative.

Liquefaction of gelatin: Weakly positive.

Acid production on chalk agar: Negative.

Urease: Positive.

Diazonium blue $\mathrm{B}$ reaction: Positive.

$\mathrm{G}+\mathrm{C}$ content of nuclear DNA: $49.5 \mathrm{~mol} \%$ (from $T_{\mathrm{m}}$ ), $47.7-48.4 \mathrm{~mol} \%$ (by HPLC) (Table 1).

Major ubiquinone: Q-10 (Table 2).

Xylose in the cells: Present.

Strains examined: Two strains were examined. The type strain K-94 was isolated by T. Nakase and B. Fungsin from a dead leaf of Imperata cylindrica, which was collected by T. Nakase and B. Fungsin at a field in the suburbs of Bangkok, Thailand, on Dec. 23, 1987. This strain (living and dried) was deposited at the Japan Collection of Microorganisms, Wako, Saitama, as JCM 7824. The living strain is maintained at the Institute for Fermentation, Osaka, Osaka, as IFO 10520, and at the Thailand Institute of Scientific and Technological Research, Bangkok, as TISTR 5590. The other strain K-35 was isolated by T. Nakase and B. Fungsin from a leaf of Oryza sativa, which was collected by K. Komagata and B. Fungsin, at a rice field in the suburbs of Bangkok, Thailand, on Dec. 17, 1987. This strain is maintained at the three culture collections mentioned above as JCM 7825, IFO 10521 and TISTR 5607.

Table 1. DNA base composition of strains of Kockovaella thailandica and Kockovaella imperatae.

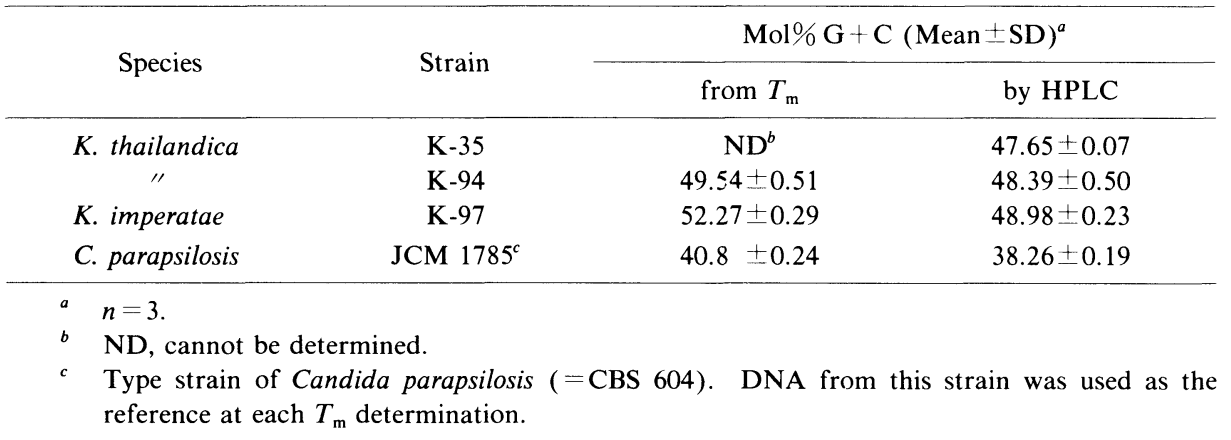

Table 2. The ubiquinone system of strains of Kockovaella thailandica and Kockovaella imperatae.

\begin{tabular}{cccc}
\hline \multirow{2}{*}{ Species } & Strain & \multicolumn{2}{c}{ Molar ratio of ubiquinone isoprenologues (\%) } \\
\cline { 3 - 4 } & & Q-9 & Q-10 \\
\hline K. thailandica & K-35 & 2.2 & 97.8 \\
" & K-94 & 2.1 & 97.9 \\
Kimperatae & K-97 & 3.2 & 96.8 \\
\hline
\end{tabular}


Kockovaella imperatae Nakase, Banno et Yamada, sp. nov.

In liquid YM post dies 3 ad $25^{\circ} \mathrm{C}$, cellulae vegetativae sphaericae vel ovoideae, 1.5-5.9 $\times 4.0-10.0 \mu \mathrm{m}$, propagantes formatione conidiorum stipitatorum et raro gemmarum blasticarum. Conidia stipitata holoblastice productantur; stipites ex cellula conidiogena multilateraliter et holoblastice exorientes. Interdum conidia in catenis et in fasciculis formantur. Separatio ex cellula conidiogena ad positonem in stipite praesens. Post unum menseum ad $17^{\circ} \mathrm{C}$, pellicula fragilis et incompleta, et sedimentum formantur. Cultura in agaro YM griseo-flava vel griseo-aurantiaca, rugosa, non-nitida, mollis vel butyracea, et margine glabra; conidia stipitata et ballistosporae formantur. Ballistosporae globosae vel napiformes, 1.4-4.6×2.1-7.4 $\mu \mathrm{m}$. Mycelium et pseudomycelium non formantur.

Fermentatio nulla. Glucosum, galactosum, L-sorbosum (lente et exiguum, vel nullum), sucrosum, maltosum, cellobiosum, trehalosum (fortasse lente), lactosum, melibiosum, raffinosum (fortasse lente), melezitosum, amylum solubile, Dxylosum, L-arabinosum, D-arabinosum (fortasse lente), D-ribosum, L-rhamnosum (fortasse lente), galactitolum (fortasse lente), D-mannitolum, D-glucitolum (fortasse exiguum), salicinum (fortasse exiguum), glucono- $\delta$-lactonum (lente), Dglucosaminum, $N$-acetyl-D-glucosaminum, acidum 2-ketogluconicum (fortasse lente ex exiguum), acidum 5-ketogluconicum (lente et exiguum), acidum Dglucuronicum, acidum D-galacturonicum, acidum succinicum (fortasse lente et exiguum), acidum citricum (lente et exiguum, vel nullum) et inositolum (lente et exiguum) assimilantur at non inulinum, ethanolum, methanolum, glycerolum, erythritolum, ribitolum (vel lente et exiguum), $\alpha$-methyl-D-glucosidum, acidum DL-lacticum nec hexadecanum. Kalium nitricum non assimilatur. Maxima temperatura crescentiae: $29-30^{\circ} \mathrm{C}$. Ad crescentiam thiaminum necessarium est. Materia amyloidea iodophila non formatur. Ureum hydrolysatur. Diazonium caeruleum B: Positivum. Proportio molaris guanini + cytosini in acido deoxyribonucleinico: $52.3 \mathrm{~mol} \%$ (ex $T_{\mathrm{m}}$ ), $49.0 \mathrm{~mol} \%$ (per HPLC). Ubiquinonum majus: Q-10. Xylosum in cellulis praesens.

Holotypus: Isolatus ex folio Imperatae cylindricae, Thailandia, xii, 1987, T. Nakase et B. Fungsin, JCM 7826 (originaliter ut K-97) conservatur in collectionibus culturarum quas 'Japan Collection of Microorganisms,' Wako, Saitama sustentat.

Growth in YM broth: After 3 days at $25^{\circ} \mathrm{C}$, the cells are spherical to ovoidal, $1.5-5.9 \times 4.0-10.0 \mu \mathrm{m}$. They propagate by conidiation on sterigma-like stalk (Fig. 3B) and budding (Figs. 3C, 3H). The conidia are produced holoblastically on a stalk which develops multilaterally and holoblastically from a mother cell (Figs. 3 B, 3C, 3I). Occasionally chains or clusters of conidia are formed. Stalks are 0.3$0.6 \mu \mathrm{m}$ wide and $4-10 \mu \mathrm{m}$ long. Daughter cells generally separate at the distal position of the stalk (Fig. 3I). A sediment is formed. After one month at $17^{\circ} \mathrm{C}$, a fragile, incomplete pellicle and a sediment are present. There may be as many as 5 stalks on a cell. 
Growth on YM agar: After one month at $17^{\circ} \mathrm{C}$, the streak culture is greyish yellow to greyish orange, delicately wrinkled, dull, soft to butyrous and has an entire margin. Stalked conidia and ballistospores are produced.

Dalmau plate culture on corn meal agar: Mycelia and pseudomycelia are not formed.

Ballistospores: Ballistospores are produced on corn meal agar and YM agar. They are globose or napiform, 1.4-4.6 $\times 2.1-7.4 \mu \mathrm{m}$, and produced on sterigmata (Figs. 3A, 3D, 3E, 3F), which are generally $4.0-5.2 \mu \mathrm{m}$ in length, but occasionally become much longer than $30 \mu \mathrm{m}$ (Fig. 3G). Sterigma may be branched with a terminal ballistospore.

Fermentation: Absent.

Assimilation of carbon compounds:

\begin{tabular}{|c|c|c|c|}
\hline Glucose & + & Glycerol & - \\
\hline Galactose & + & Erythritol & - \\
\hline L-Sorbose & $\begin{array}{r}+ \text { (latent } \& \\
\text { weak) or }\end{array}$ & $\begin{array}{l}\text { Ribitol } \\
\text { - Galactitol }\end{array}$ & $\begin{array}{l}- \text { or }+ \text { (latent } \& \text { weak }) \\
+ \text { (may be latent })\end{array}$ \\
\hline Sucrose & + & D-Mannitol & + \\
\hline Maltose & + & D-Glucitol & + (may be weak) \\
\hline Cellobiose & + & $\alpha$-Methyl-D-glucoside & - \\
\hline Trehalose & $\begin{array}{l}+ \text { (may be } \\
\text { latent) }\end{array}$ & Salicin & + (may be weak) \\
\hline Lactose & + & Glucono- $\delta$-lactone & + (latent) \\
\hline Melibiose & + & D-Glucosamine & + \\
\hline Raffinose & $+\underset{\text { latent })}{\text { (may be }}$ & $N$-Acetyl-D-glucosamine & + \\
\hline Melezitose & + & 2-Ketogluconic acid & $+($ may be latent $\&$ weak $)$ \\
\hline Inulin & - & 5-Ketogluconic acid & + (latent \& weak) \\
\hline Soluble starch & + & D-Glucuronic acid & + \\
\hline D-Xylose & + & D-Galacturonic acid & + \\
\hline L-Arabinose & + & DL-Lactic acid & - \\
\hline D-Arabinose & $\begin{array}{c}+ \text { (may be } \\
\text { latent) }\end{array}$ & Succinic acid & + (may be latent $\&$ weak $)$ \\
\hline D-Ribose & + & Citric acid & + (latent \& weak) or - \\
\hline L-Rhamnose & $+\underset{\text { latent })}{\text { (may be }}$ & Inositol & + (latent \& weak) \\
\hline Ethanol & - & Hexadecane & - \\
\hline Methanol & - & & \\
\hline
\end{tabular}

Assimilation of nitrogen compounds:

Ammonium sulfate + Ethylamine hydrochloride -

Potassium nitrate - $\quad$ L-Lysine hydrochloride +

Sodium nitrite $\quad-\quad$ Cadaverine dihydrochloride --

Maximum growth temperature: $29-30^{\circ} \mathrm{C}$.

Vitamin required: Thiamine. 
Growth on 50\% (w/w) glucose-yeast extract agar: Negative.

Production of starch-like substances: Negative.

Liquefaction of gelatin: Weakly positive.

Acid production on chalk agar: Negative.

Urease: Positive.

Diazonium blue $\mathrm{B}$ reaction: Positive.

$\mathrm{G}+\mathrm{C}$ content of nuclear DNA: $52.3 \mathrm{~mol} \%$ (from $T_{\mathrm{m}}$ ), $49.0 \mathrm{~mol} \%$ (by HPLC) (Table 1).

Major ubiquinone: Q-10 (Table 2).

Xylose in the cells: Positive.

Type strain: K-97, isolated by T. Nakase and B. Fungsin from a leaf of Imperata cylindrica, which was collected by $\mathrm{T}$. Nakase and B. Fungsin, at a field in the suburbs of Bangkok, Thailand, on Dec. 23, 1987. This strain (living and dried) is deposited at the Japan Collection of Microorganisms, Wako, Saitama, as JCM 7826. The living strain is also maintained at the Institute for Fermentation, Osaka, Osaka, as IFO 10522 and the Thailand Institute of Scientific and Technological Research, Bangkok, as TISTR 5592.

The mode of vegetative reproduction

In "The Yeasts, a Taxonomic Study," 3rd ed. (1984), stalked conidiumforming yeasts were clearly separated from ballistospore-forming yeasts in the reproduction of stalked conidia and the lack of both budding yeast cells and ballistospores $(5-7,29)$. All of stalked conidium-forming yeasts were placed in Sterigmatomyces and its supposed teleomorphic genus Sterigmatosporidium. Later, Yamada and Banno(36) proposed a new genus Fellomyces for Q-10-equipped species of Sterigmatomyces whose conidia were liberated by an end-break. Two Q9-equipped species, Sterigmatomyces elviae and Sterigmatomyces halophilus, whose conidia are liberated in the mid-region of sterigmata are retained in Sterigmatomyces.

In 1987, however, van der Walt et al. (35) reported that a strain of Sterigmatomyces wingfieldii, a new species of stalked conidium-forming non-ballistosporous yeast, reproduced also by budding cells. Yamada et al. (38) transferred this species to a newly proposed monotypic genus Tsuchiyaea because it had xylose in the cells that was different from species retained in Sterigmatomyces. They also excluded Fellomyces nectairei from Fellomyces and transferred it to a newly proposed monotypic genus Kurtzmanomyces because xylose was not detected in its cells (37). The validity of these new genera was supported by partial sequencing studies of 18 $\mathrm{S}$ and $25 / 26 \mathrm{~S}$ rRNAs $(9,41)$.

Further, in 1989, Nakase et al. (26) reported that two ballistosporous yeast strains, which were found on the surface of plants in Japan, usually reproduced by non-ballistosporous stalked conidia but never by budding yeast cells. They placed these strains in a newly proposed genus Ballistosporomyces. Chemotaxonomically, this genus is characterized by the lack of xylose in the cells and Q-10 as the major 
ubiquinone. In that paper, they used a term "non-ballistosporous conidium" for non-ballistosporous stalked conidium instead of "sterigmatoconidium" which was previously introduced by Nakase (20), to prevent further confusion in the terminology. However, "non-ballistosporous conidium" cannot specify this type of conidium since blastoconidium is included in this term. Therefore, in the present paper, we decided to use "stalked conidium" which was used by van der Walt et al. (35) for this type of conidium.

In the present study, three different modes of conidiogenesis were observed in strains of Kockovaella (Figs. 1-3). They usually reproduce by stalked conidia and often by ballistospores. Rarely they reproduce by budding yeast cells.

The studies of $S$. wingfieldii ( $\equiv T$. wingfieldii) and Ballistosporomyces raised a question regarding the significance of the mode of conidiogenesis as a taxonomic criterion for yeasts. This question was strengthened by the finding of Kockovaella. As will be discussed in a later paragraph, a close relationship of Kockovaella to species of non-ballistosporous genera Fellomyces and Sterigmatosporidium is suggested based on comparisons of the partial sequence of $18 \mathrm{~S}$ rRNA. As discussed by Nakase et al. (22), the presence or the absence of stalked conidia, ballistospores and budding yeast cells seems to be not so important as a criterion in the systematics of basidiomycetous yeasts.

\section{Morphology of ballistospores}

Strains of $K$. thailandica produce kidney-shaped or ellipsoidal ballistospores which are included in the category of typical asymmetrical (bilaterally symmetrical) ballistospores. On the other hand, the strain of $K$. imperatae produces globose to napiform ballistospores which are included in the category of typical symmetrical (rotationally symmetrical) ballistospores. The symmetry or the asymmetry of ballistospores has been considered for a long time to be an important taxonomic criterion to distinguish the taxonomic rank genus and is used to separate the genera Bullera and Sporobolomyces $(16,27,28)$. According to Johri and Bandoni (11), the ballistospores of both genera are essentially bilaterally symmetrical; like basidiospores, they have an apiculus and a flattened adaxial surface. Nakase and Boekhout (21) used these terms from a practical point of view, as most species of Bullera have nearly rotationally symmetrical, globose, obovoid to ampulliform ballistospore bodies and most species of Sporobolomyces have conspicuously bilaterally symmetrical bodies of the ballistospores. Bullera piricola (30), Bullera megalospora (18) and Sporidiobolus pararoseus (1) were reported to produce both asymmetrical and symmetrical ballistospores, but they never produce globose, obovoid or ampulliform ballistospores. The symmetrical ballistospores of these species are longer than rotationally symmetrical ballistospores found in typical Bullera. The former two species belong to an atypical group of Bullera (20).

As will be discussed in later paragraphs, $K$. thailandica and $K$. imperatae are assumed to be closely related based on the identical base sequence in the positions 1451 through 1618 of $18 \mathrm{~S}$ rRNA and on the resemblance of phenotypical 


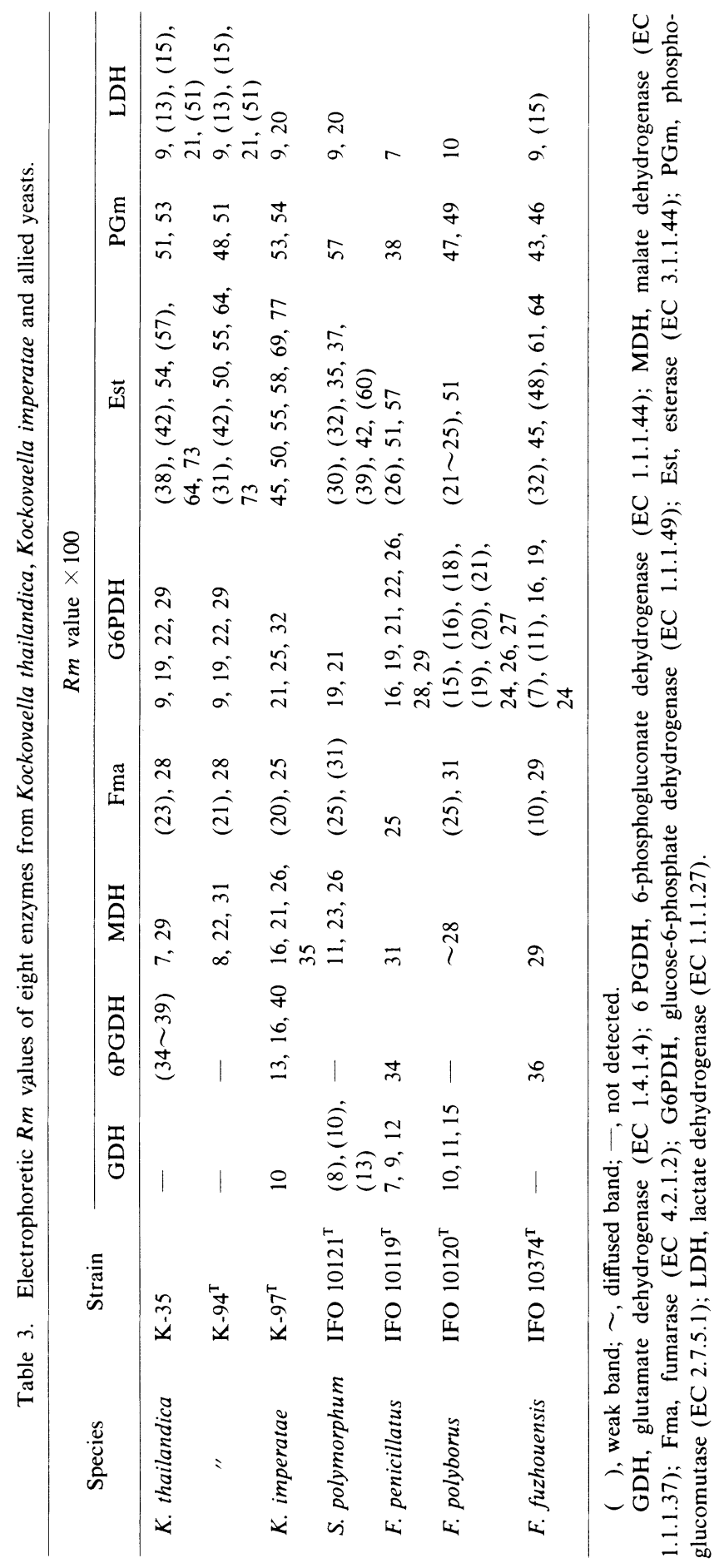


characteristics. The fact that two such closely related two yeasts produce quite different shaped ballistospores, typical asymmetrical and typical symmetrical, may arouse a question regarding the taxonomic significance of the types of ballistospores. However, the morphology of ballistospores is believed to be a convenient taxonomic criterion to define a taxonomic rank species.

\section{Electrophoretic comparison of enzymes}

The electrophoretic enzyme patterns were compared to determine the difference between $K$. thailandica and $K$. imperatae at the specific rank, together with supposedly related species of basidiomycetous yeasts in the genera Fellomyces and Sterigmatosporidium which contain xylose in the cells and have Q-10 as the major ubiquinone.

The relative mobilities $(\mathrm{Rm})$ of eight enzymes examined are shown in Table 3. Similarities of enzyme pattern were calculated based on $R m$ values and are shown in a triangle matrix (Fig. 4). Two strains of Kockovaella thailandica showed $49.8 \%$ similarity to each other and are considered to comprise a single species. A low similarity, 6.2-7.1\%, was found between $K$. thailandica and $K$. imperatae. This clearly suggested a difference between these two species at the specific rank. Fellomyces fuzhouensis, $F$. polyborus, $F$. penicillatus and Sterigmatosporidium polymorphum showed low similarities, below $29.7 \%$, to Kockovaella species.

\section{$D N A$ base composition and DNA-DNA reassociation}

The $\mathrm{mol} \% \mathrm{G}+\mathrm{C}$ of $K$. imperatae was $52.3 \mathrm{~mol} \%$ which is about $2.7 \%$ higher than those of $K$. thailandica, when it was calculated from $T_{\mathrm{m}}$ (Table 1). DNA from $K$. thailandica K-35 showed an abnormal melting curve so that the correct $T_{\mathrm{m}}$ cannot be determined. The $\mathrm{G}+\mathrm{C}$ values of three isolates were similar to one another when they were analyzed by HPLC after hydrolysis of DNA. So, it is difficult to judge whether the $\mathrm{G}+\mathrm{C}$ values of $K$. thailandica and $K$. imperatae are

Kockovaella thailandica K 94

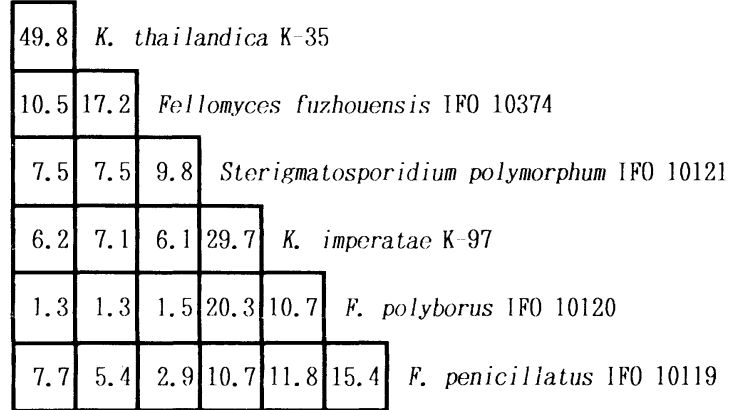

Fig. 4. The similarity matrix based on the electrophoretic patterns of eight enzymes from strains of Kockovaella thailandica, Kockovaella imperatae, and related basidiomycetous yeasts. Numerals indicate \% similarities among strains. 
Table 4. DNA similarity among species of the genera Kockovaella, Fellomyces, Kurtzmanomyces and Tsuchiyaea.

\begin{tabular}{|c|c|c|c|c|}
\hline \multirow{3}{*}{ Strains } & & \multicolumn{3}{|c|}{ Homology value $(\%)$} \\
\hline & & \multicolumn{3}{|c|}{ Probe DNA of } \\
\hline & & $\begin{array}{c}\text { K. thailandica } \\
\text { K-35 }\end{array}$ & $\begin{array}{l}\text { F. fuzhouensis } \\
\text { IFO } 10374\end{array}$ & $\begin{array}{c}\text { F. polyborus } \\
\text { IFO } 10120\end{array}$ \\
\hline Kockovaella thailandica & $\mathrm{K}-35$ & 100 & 11 & 3 \\
\hline K. thailandica & $\mathrm{K}-94^{\mathrm{T}}$ & 110 & 13 & 3 \\
\hline K. imperatae & $K-97^{\mathrm{T}}$ & 33 & 6 & $\mathrm{NT}^{a}$ \\
\hline Fellomyces fuzhouensis & IFO $10374^{\mathrm{T}}$ & 9 & 100 & 4 \\
\hline F. penicillatus & IFO $10119^{\mathrm{T}}$ & 6 & 4 & 30 \\
\hline F. polyborus & IFO $10120^{\mathrm{T}}$ & 4 & 7 & 100 \\
\hline Kurtzmanomyces nectairei & IFO $10118^{\mathrm{T}}$ & $\mathrm{NT}^{a}$ & 4 & 0 \\
\hline
\end{tabular}

different. The discrepancy of $\mathrm{G}+\mathrm{C}$ values between $T_{\mathrm{m}}$ and HPLC methods is sometimes encountered especially in basidiomycetous yeasts $(23,24,26)$ but the reason is not yet known.

DNA-DNA relatedness between certain species pairs among Kockovaella and stalked conidium-forming and Q-10 equipped yeast genera, Fellomyces and Kurtzmanomyces, is shown in Table 4. Two strains K-94 and K-35 showed 100\% similarity and should be considered to be members of a single species, $K$. thailandica. $K$. thailandica $\mathrm{K}-35$ exhibited $33 \%$ similarity to $K$. imperatae K-97 and it was evident that the two yeasts were separate species, although the two were somewhat related to each other. The levels of DNA similarities of strains K-35, K-94 and K97 of Kockovaella to species of Fellomyces, Tsuchiyaea, and Kurtzmanomyces range from 2 to 13\%. These facts indicate that the two species of Kockovaella are genetically distinct from the species of the other three genera.

As mentioned above, $K$. thailandica and $K$. imperatae are judged to be different species based on the electrophoretic comparison of enzymes and DNA-DNA reassociation experiment. Practically, they can be easily distinguished from each other by the morphology of ballistospores, maximum growth temperature and the assimilability of galactitol.

The generic name "Kockovaella" was chosen in honor of Dr. A. KockováKratochvílová for her great contributions to yeast taxonomy.

\section{Taxonomic and phylogenetic position of Kockovaella}

The partial primary sequences of positions 1451 through 1618 of 18S rRNA of the five strains, $K$. thailandica K-35 and K-94, $K$. imperatae K-97, Bullera alba JCM 2954 and B. megalospora JCM 5269, were aligned (Fig. 5). The number of base differences were calculated using these sequences and those of supposedly related species of xylose-containing, stalked conidium-forming yeasts reported in 


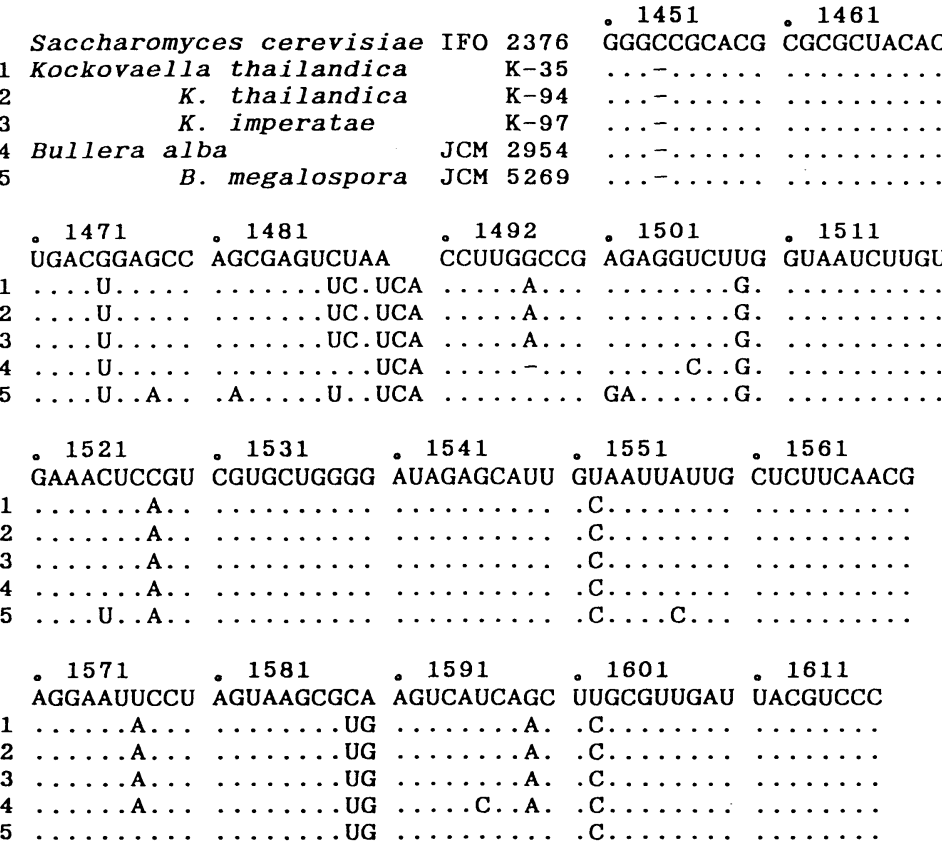

Fig. 5. Primary structure of partial base sequences of 18S rRNA of Kockovaella and some species of Bullera.

K. thai landiaca K 35

\begin{tabular}{|c|c|c|c|c|c|c|c|c|c|}
\hline 0 & \multicolumn{9}{|c|}{ K. thailandica K 94} \\
\hline 0 & 0 & \multicolumn{8}{|c|}{ K. imperatae K-97 } \\
\hline 5 & 5 & 5 & \multicolumn{7}{|c|}{ B. alba JCM 2954} \\
\hline 10 & 10 & 10 & 12 & \multicolumn{6}{|c|}{ B. mega lospora JCM 5269} \\
\hline 4 & 4 & 4 & 5 & 12 & \multicolumn{5}{|c|}{ F. penicillatus" } \\
\hline 4 & 4 & 4 & 5 & 12 & 0 & \multicolumn{4}{|c|}{ F. polyborus ${ }^{\mathrm{a}}$} \\
\hline 2 & 2 & 2 & 6 & 10 & 2 & 2 & $F$. & fuzho & uens is \\
\hline 3 & 3 & 3 & 6 & 12 & 3 & 3 & 3 & S. $p$ & ol ymorphum" \\
\hline 7 & 7 & 7 & 7 & 13 & 6 & 6 & 7 & 5 & T. wing ie \\
\hline
\end{tabular}

Fig. 6. Triangle matrix based on the calculated number of the base differences in the partial sequences of the positions 1451 through 1618 of $18 \mathrm{~S}$ rRNA of strains of Kockovaella and related yeasts. ${ }^{a}$ Data were those reported in references 9 and 41 . 
the literature (Fig. 6). Two strains of $K$. thailandica and the strain of $K$. imperatae showed the identical base sequences. This suggested a close affinity between $K$. thailandica and $K$. imperatae in spite of the fact that these two species produced ballistospores of quite different types. As mentioned above, the type of ballistospores has been considered to be an important criterion to separate the taxonomic rank genus. But the present findings suggest that ballistospore types are not of primary importance in yeast taxonomy.

The partial base sequences of the five species of xylose containing, stalked conidium-forming yeast genera Fellomyces, Tsuchiyaea and Sterigmatosporidium species were compared with Kockovaella species using the data reported in the literature $(9,41)$. Recently, Fellomyces and Tsuchiyaea were excluded from Sterigmatomyces and were proposed as respective new genera based mainly on the presence of xylose in the cells and ubiquinone types, Q-10 for the former and Q-9 for the latter $(36,38)$. Guého et al. (9) supported this reclassification based on the sequencing study of $18 \mathrm{~S}$ and $25 \mathrm{~S}$ rRNAs. As shown in Fig. 5, the base differences among strains of Kockovaella, Fellomyces and Sterigmatosporidium, a supposed teleomorph of Fellomyces, were found to be two to four. In the dondrogram calculated based on the base differences, strains of these three genera comprised a single cluster (Fig. 7). This suggested a phylogenetically close relationship among these yeasts.

Guého et al. $(8,9)$ and Yamada et al. $(40,42)$ reported the partial sequences of $18 \mathrm{~S}$ and $25 / 26 \mathrm{~S}$ ribosomal RNAs of yeasts belonging to several genera of ascomycetous and basidiomycetous yeasts and discussed the phylogenetic relationships among yeasts. In the present study, we compared only 168 bases (in Saccharomyces cerevisiae) of $18 \mathrm{~S}$ rRNA. The determination of the sequences of other positions of

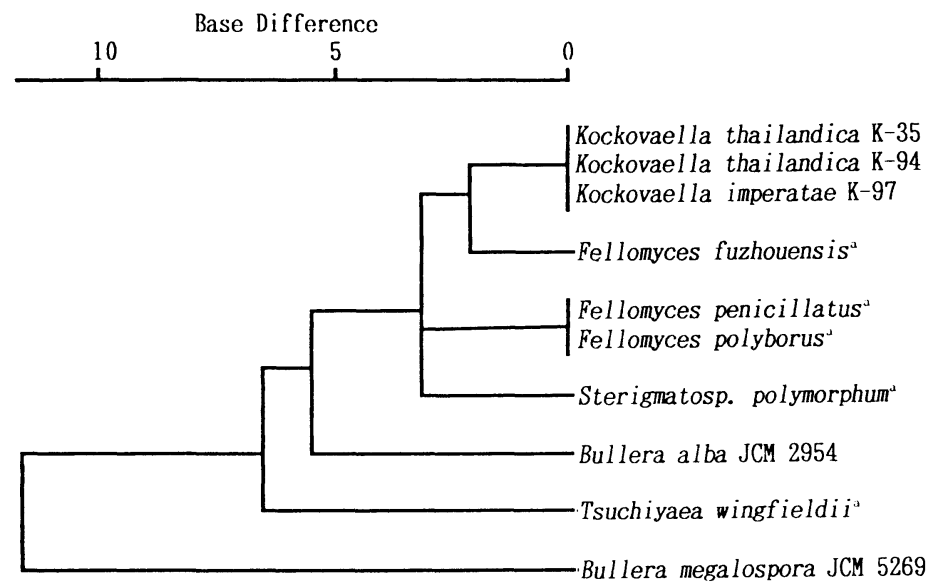

Fig. 7. Dendrogram based on the base differences of the partial sequences of positions 1451 through 1618 of $18 \mathrm{~S}$ rRNA of xylose-containing ballistosporous yeasts and related genera (prepared by the unweighted pair-group average method). ${ }^{a}$ Data were those reported in references 9 and 41 . 
18S rRNA or the use of other molecular species of RNA is required for further detailed discussion on the phylogenetic relationship among ballistosporous yeasts.

From the above facts, it is apparent that all of the non-ballistosporous basidiomycetous yeasts may produce ballistospores. Further extensive molecular study is required to confirm this. Apparently, the presence or absence of ballistospores does not reflect the phylogenetic relationship among basidiomycetous yeasts and is not considered to be a proper criterion to define genera taxonomically.

Probably, drastic change of taxonomic system of basidiomycetous anamorphic yeasts are required in the future when sufficient molecular data are accumulated. Until then, to prevent the confusion of taxonomy of yeasts and to avoid frequent changes of scientific names of species, we should maintain a taxonomic system based on the mode of conidiogenesis combined with certain chemotaxonomic criteria such as the presence or absence of xylose in the cells and the ubiquinone system. Based on these characteristics, the genus Kockovaella is easily distinguished from the known genera of ballistospore-forming yeasts and those of stalked conidium-forming yeasts (Table 5).

Kockovaella species are not considered to be closely related to B. alba, $T$. wingfieldii and $B$. megalospora and another species of xylose-containing genera of basidiomycetous yeasts (Figs. 6,7). Furthermore, Bullera alba and B. megalospora are not closely related to each other because 12 bases are different in the positions examined (Fig. 6). Nakase (20) separated three species of Bullera, which form large and asymmetrical ballistospores, from typical species of Bullera and called them the "piricola group." Bullera megalospora was included in this group. Further sequencing study of RNAs is required to evaluate significance of this grouping using all of the known species of Bullera.

We thank Miss P. Atthasampunna, Mrs. W. Potacharoen and Mr. B. Fungsin, Thailand Institute of Scientific and Technological Research, Bangkok, Thailand, and Prof. K. Komagata, Tokyo Uni-

Table 5. Salient characteristics among Kockovaella and allied genera.

\begin{tabular}{|c|c|c|c|c|c|c|}
\hline Teleomorph & Anamorph & $\begin{array}{l}\text { Xylose } \\
\text { in the } \\
\text { cells }\end{array}$ & $\begin{array}{c}\text { Major } \\
\text { ubiquinone }\end{array}$ & $\begin{array}{c}\text { Ballisto- } \\
\text { spores }\end{array}$ & $\begin{array}{l}\text { Stalked } \\
\text { conidia }\end{array}$ & $\begin{array}{c}\text { Budding } \\
\text { cells }\end{array}$ \\
\hline$?$ & Ballistosporomyces & - & Q-10 & + & + & \\
\hline$?$ & Kurtzmanomyces & - & Q-10 & - & + & - \\
\hline Sporidiobolus & Sporobolomyces & - & $\begin{array}{c}\text { Q-10 } \\
\text { or Q-10 }\left(\mathrm{H}_{2}\right)^{a}\end{array}$ & + & - & + \\
\hline$?$ & Sterigmatomyces & - & Q-9 & - & + & - \\
\hline$?$ & Bensingtonia & - & Q-9 & + & - & + \\
\hline$?$ & Kockovaella & + & Q-10 & + & + & + \\
\hline$?$ & Bullera & + & Q-10 & + & - & + \\
\hline Sterigmatosporidium? & Fellomyces & + & Q-10 & - & + & $\ldots$ \\
\hline$?$ & Tsuchiyaea & + & Q-9 & - & + & + \\
\hline
\end{tabular}

a Sporobolomyces elongatus. 
versity of Agriculture, Tokyo, for their help in collecting plant materials and the isolation of the strains reported in this paper, and Mrs. T. Sadakorn, Botany Section, The Herbarium BK, Department of Agriculture, Ministry of Agriculture and Cooperative, Bangkok, Thailand, for the identification of plants from which the yeasts were isolated. We also express our thanks to Prof. J. Sugiyama, Institute of Applied Microbiology, The University of Tokyo, Tokyo, for his help in the preparation of the Latin diagnoses.

\section{REFERENCES}

1) de Hoog, G. S., Morphology of anamorphs, II. Sporidiobolus and Sporobolomyces. Stud. Mycol., 22, 10-14 (1982).

2) Derx, H. G., Étude sur les Sporobolomycètes. Ann. Mycol., 28, 1-23 (1930).

3) Ezaki, T., Hashimoto, Y., Takeuchi, N., Miura, H., Matsui, Y., and Yabuuchi, E., Simple genetic identification method of viridans group streptococci by colorimetric dot hybridization and quantitative fluorometric hybridization in microdilution wells. J. Clin. Microbiol., 26, 1708-1731 (1988).

4) Ezaki, T., Hashimoto, Y., and Yabuuchi, E., Fluorometric deoxyribonucleic acid-deoxyribonucleic acid hybridization in microdilution wells as an alternative to membrane filter hybridization in which radioisotopes are used to determine genetic relatedness among bacterial strains. Int. J. Syst. Bacteriol., 39, 224-229 (1989).

$5)$ Fell, J. W. and Statzell Tallman, A., Genus Sporidiobolus Nyland. In The Yeasts, a Taxonomic Study, 3rd ed., ed. by Kreger-van Rij, N. J. W., Elsevier Sci. Publ., Amsterdam (1984), p. 532540.

6) Fell, J. W. and Statzell Tallman, A., Genus Sporobolomyces Kluyver et van Niel. In The Yeasts, a Taxonomic Study, 3rd ed., ed. by Kreger-van Rij, N. J. W., Elsevier Sci. Publ., Amsterdam (1984), p. 911-920.

7) Fell, J. W., Statzell Tallman, A., and Kurtzman, C. P., Genus Sterigmatomyces Fell. In The Yeasts, a Taxonomic Study, 3rd ed., ed. by Kreger-van Rij, N. J. W., Elsevier Sci. Publ., Amsterdam (1984), p. 921-929.

8) Guého, E., Kurtzman, C. P., and Perterson, S. W., Evolutionary affinities of heterobasidiomycetous yeasts estimated from $18 \mathrm{~S}$ and $25 \mathrm{~S}$ ribosomal RNA sequence divergence. Syst. Appl. Microbiol., 12, 230-236 (1989).

9) Guého, E., Kurtzman, C. P., and Perterson, S. W., Phylogenetic relationships among species of Sterigmatomyces and Fellomyces as determined from partial rRNA sequences. Int. J. Syst. Bacteriol., 40, 60-65 (1990).

10) Ingold, C. T., Bensingtonia ciliata gen. et sp. nov., a ballistosporic fungus. Trans. Br. Mycol. Soc., 86, 325-328 (1986).

11) Johri, B. N. and Bandoni, R. J., Taxonomy of the sporobolomycetous genus Bullera. Proc. Int. Symp. Taxon. Fungi, Madras, 2, 536-547 (1984).

12) Komagata, K. and Nakase, T., Reitoshokuhin no biseibutsu ni kansuru kenkyu. V. Shihan reitoshokuhin yori bunri shita kobo no seijo (Microbiological studies on frozen foods. V. General properties of yeasts isolated from frozen foods) (in Japanese). Shokuhin Eiseigaku Zasshi, 8, 5357 (1967).

13) Kreger-van Rij, N. J. W. (ed.), The Yeasts, a Taxonomic Study, 3rd ed., Elsevier Sci. Publ., Amsterdam (1984), p. 1-1082.

14) Lane, D. J., Pace, B., Olson, G. J., Stahl, D. A., Sogin, M. L., and Pace, N. R., Rapid determination of $16 \mathrm{~S}$ ribosomal RNA sequences for phylogenetic analysis. Proc. Natl. Acad. Sci. USA, 82, 6955-6959 (1985).

15) Langtime, M., Rapid isolation of yeast DNA. In Current Protocols in Molecular Biology, ed. by Ausubel, F. M., Brent, R., Kington, R. E., Moore, D. G., Seidman, J. G., Smith, J. A., and Struhl, 
K., Supplement 8, Subscriber's Notebook, John Wiley \& Sons, New York (1989).

16) Lodder, J. and Kreger-van Rij, N. J. W., The Yeasts, a Taxonomic Study, North-Holland Publ. Co., Amsterdam (1952), p. 1-713.

17) Mankin, A. S., Skryabin, K. G., and Rubtsov, P. M., Identification of ten additional nucleotides in the primary structure of yeast 18S rRNA. Gene, 44, 143-145 (1986).

18) Nakase, T. and Suzuki, M., Bullera megalospora, a new species of yeast forming large ballistospores isolated from dead leaves of Oryza sativa, Miscanthus sinensis and Sasa sp. in Japan. J. Gen. Appl. Microbiol., 32, 225-240 (1986).

19) Nakase, T. and Suzuki, M., The ubiquinone system in strains of species in the ballistosporeforming yeast genera Sporidiobolus, Sporobolomyces and Bullera. J. Gen. Appl. Microbiol., 32, 251258 (1986).

20) Nakase, T., Isolation and maintenance of ballistospore-forming yeasts. Stud. Mycol., 30, 375-387 (1987).

21) Nakase, T. and Boekhout, T., Emendation of the genus Bensingtonia Ingold. J. Gen. Appl. Microbiol., 34, 433-437 (1988).

22) Nakase, T., Hamamoto, M., and Sugiyama, J., Recent progresses in the systematics of basidiomycetous yeasts. Jpn. J. Med. Mycol., in press.

23) Nakase, T., Itoh, M., Takematsu, A., and Bandoni, R. J., Bullera miyagiana, a new species of ballistospore-forming yeast isolated from Abies firma collected in Japan. J. Gen. Appl. Microbiol., 36, 33-39 (1990).

24) Nakase, T., Takematsu, A., Itoh, M., and Boekhout, T., Conspecificity of Bullera derxii, Bullera sinensis and Bullera sinensis var. lactis. J. Gen. Appl. Microbiol., 36, 209-213 (1990).

25) Nakase, T., Itoh, M., and Sugiyama, J., Bensingtonia ingoldii sp. nov., a ballistospore-forming yeast isolated from Knightia excelsa collected in New Zealand. J. Gen. Appl. Microbiol., 35, 53-58 (1989).

26) Nakase, T., Okada, G., Sugiyama, J., Itoh, M., and Suzuki, M., Ballistosporomyces, a new ballistospore-forming anamorphic yeast genus. J. Gen. Appl. Microbiol., 35, 289-309 (1989).

27) Phaff, H. J., Genus Bullera Derx. In The Yeasts, a Taxonomic Study, 2nd ed., ed. by Lodder, J., North-Holland Publ., Amsterdam (1970), p. 815-821.

28 ) Phaff, H. J., Genus Sporobolomyces Kluyver et van Niel. In The Yeasts, a Taxonomic Study, 2nd ed., ed. by Lodder, J., North-Holland Publ., Amsterdam (1970), p. 830-862.

29) Rodrigues de Miranda, L., Genus Bullera Derx. In The Yeasts, a Taxonomic Study, 3rd ed., ed. by Kreger-van Rij, N. J. W., Elsevier Sci. Publ., Amsterdam (1984), p. 577-584.

30) Stadelmann, F., A new species of the genus Bullera Derx. Antonie van Leeuwenhoek J. Microbiol. Serol., 41, 575-582 (1975).

31) Suzuki, K., Kakusan no bunseki. I. DNA enki sosei. In Atarashii bunrui-gaku ni bansou suru saikin dotei ho: Hyogen keishitsu no kan-i shiken kara kakusan no bunseki made (The analysis of nucleic acids. I. DNA base composition. In Bacterial Identification in Accordance with Recent Taxonomy: Use of Phenotypic, Chemical, and Genetic Analysis) (in Japanese), ed. by the Education Committee, Japanese Society for Bacteriology, Saikon Publ., Tokyo (1987), p. 88-97.

32) Suzuki, M. and Nakase, T., The distribution of xylose in the cells of ballistosporous yeastsApplication of high performance liquid chromatography without derivatization to the analysis of xylose in whole cell hydrolysates. J. Gen. Appl. Microbiol., 34, 95-103 (1988).

33) van der Walt, J. P., Criteria and methods used in classification. In The Yeasts, a Taxonomic Study, 2nd ed., ed. by Lodder, J., North-Holland Publ., Amsterdam (1970), p. 34-133.

34) van der Walt, J. P. and Yarrow, D., Methods for the isolation, maintenance, classification and identification of yeasts. In The Yeasts, a Taxonomic Study, 3rd ed., ed. by Kreger-van Rij, N. J. W., Elsevier Sci. Publ., Amsterdam (1984), p. 45-105.

35) van der Walt, J. P., Yamada, Y., Ferreira, N. P., and Richards, P. D. G., New basidiomycetous yeasts from Southern Africa. II. Sterigmatomyces wingfieldii sp. n. Antonie van Leeuwenhoek J. Microbiol., 53, 137-142 (1987). 
36) Yamada, Y. and Banno, I., Fellomyces, a new anamorphic yeast genus for the $\mathrm{Q}_{10}$-equipped organisms whose conidium is freed by an end-break in the sterigma. J. Gen. Appl. Microbiol., 30, 523-525 (1984).

37) Yamada, Y., Itoh, M., Kawasaki, H., Banno, I., and Nakase, T., Kurtzmanomyces gen. nov., an anamorphic yeast genus for the $\mathrm{Q}_{10}$-equipped organism whose conidium is freed by an end-break in the sterigma which branches or elongates to produce additional conidia and whose cells contain no xylose. J. Gen. Appl. Microbiol., 34, 503-506 (1988).

38) Yamada, Y., Kawasaki, H., Itoh, M., Banno, I., and Nakase, T., Tsuchiyaea gen. nov., an anamorphic yeast genus for the $\mathrm{Q}_{9}$-equipped organism whose reproduction is either by enteroblastic budding or by the formation of conidia which are disjointed at a septum in the mid-region of the sterigmata and whose cells contain xylose. J. Gen. Appl. Microbiol., 34, 507-510 (1988).

39) Yamada, Y., Nakagawa, Y., and van der Walt, J. P., Bensingtonia phylladus, a new combination for the $\mathrm{Q}_{9}$-equipped species, Sporobolomyces phylladus. Agric. Biol. Chem., 52, 3203 (1988).

40) Yamada, Y. and Kawasaki, H., The molecular phylogeny of the $\mathrm{Q}_{8}$-equipped basidiomycetous yeast genera Mrakia Yamada et Komagata and Cystofilobasidium Oberwinkler et Bandoni based on the partial sequences of $18 \mathrm{~S}$ and $26 \mathrm{~S}$ ribosomal ribonucleic acids. J. Gen. Appl. Microbiol., 35, 173-183 (1989).

41) Yamada, Y., Kawasaki, H., Nakase, T., and Banno, I., The phylogenetic relationship of the conidium-forming yeast genera Sterigmatomyces, Kurtzmanomyces, Tsuchiyaea and Fellomyces and the teleomorphic yeast genus Sterigmatosporidium on the basis of the partial sequences of 18 S and 26S ribosomal ribonucleic acids. Agric. Biol. Chem., 53, 2993-3001 (1989).

42) Yamada, Y., Nakagawa, Y., and Banno, I., The phylogenetic relationship of the $Q_{9}$-equipped species of the heterobasidiomycetous yeast genera Rhodosporidium and Leucosporidium based on the partial sequences of $18 \mathrm{~S}$ and $26 \mathrm{~S}$ ribosomal ribonucleic acids: The proposal of a new genus Kondoa. J. Gen. Appl. Microbiol., 35, 377-385 (1989).

43) Yamazaki, M. and Komagata, K., Taxonomic significance of electrophoretic comparison of enzymes in the genera Rhodotorula and Rhodosporidium. Int. J. Syst. Bacteriol., 31, 361-381 (1981). 